Acta vet. scand. $1970,11,495-509$.

From the Department of Animal Husbandry and Genetics and the Department of Pathology, Veterinary College of Norway, Oslo.

\title{
THE VITAMIN E-DEFICIENCY SYNDROME IN PIGS
}

\author{
II. INVESTIGATIONS ON SERUM AND TISSUE \\ ENZYME ACTIVITY
}

\author{
By \\ Sverre Tollersrud and Inger Nafstad
}

As demonstrated by Nafstad \& Tollersrud (1970) in a previous paper a vitamin E-deficient diet fed to pigs can give rise to pathologic changes in different organs such as myocardium, liver, skeletal muscles, blood vessels, etc. The dominant postmortem diagnosis will, depending on the organ most affected, vary between "Mulberry heart disease" ("Plötzlicher Herztod”), toxic liver dystrophy (Hepatosis diaetetica), muscular dystrophy, or vascular injuries.

Usually a complexity of these pathologic changes occurs simultaneously and an exact clinical diagnosis can consequently hardly be made. Furthermore, vitamin E-deficient pigs often die very suddenly without having shown symptoms of disease.

In order to try to obtain some information about the development of the vitamin E-deficiency syndrome, all animals in the feeding experiments described in the previous paper were routinely followed with serum enzyme investigations. Blood enzyme levels may provide information relative to the nature of a disease as well as serving as diagnostic aids. The pigs were regularly tested on serum aspartate aminotransferase and alanine aminotransferase. In some series isocitrate dehydrogenase and lactate dehydrogenase were also determined ${ }^{1}$ ).

1) The nomenclature for enzymes suggested in the Report of the Commission on Enzymes (1961) is used in this paper. Abbreviations introduced by other authors in accordance with the new systematic 
In two experiments the transferase activity of tissue homogenates was determined after necropsy. The results were compared to the serum levels in vivo and to the post-mortem findings in deficient as well as in supplemented animals.

Aspartate aminotransferase and alanine aminotransferase are intracellular enzymes present in most animal tissues. Injuries or degeneration of a tissue will cause an enzyme leakage to the blood vessels, with a subsequent elevation of the enzyme activity. The increase depends on the organ affected and the extent of tissue damage.

Myocardial tissue has the highest activity of both transferases. Swine liver is also rich in aspartate aminotransferase, but has, unlike human liver, a rather low content of alanine aminotransferase (Wretlind et al. 1959, Cornelius et al. 1959). Accordingly, pigs suffering from liver diseases in theory should show a high serum aspartate aminotransferase activity and moderately increased alanine aminotransferase values. With myocardial injuries such as "Mulberry heart" high serum levels of both enzymes should be expected.

Isocitrate dehydrogenase is also present in all animal tissues, but has been found more "liver specific" than the transferases. With liver damage a heavy rise of this enzyme will be observed, whereas myopathies cause a less marked serum elevation (Sterkel et al. 1958).

Total lactate dehydrogenase might be increased in both liver necrosis and following a myocardial injury. In human medicine lactate dehydrogenase determinations may be preferred to aspartate aminotransferase in cases of myocardial diseases because it remains elevated for a longer period after infarction.

\section{MATERIAL AND METHODS}

Concerning experimental animals and detailed feeding plans reference is made to the previous paper (Nafstad \& Tollersrud 1970).

and trivial names are used in tables and figure. Aspartate aminotransferase (EC 2.6.1.1), AspAT, previously known as glutamate-oxalacetatetransaminase (GOT). Alanine aminotransferase (EC 2.6.1.2), AlAT, previously named glutamate-pyruvate-transaminase (GPT). Lactate dehydrogenase (EC 1.1.1.27), LDH. NADP isocitrate dehydrogenase (EC 1.1.1.42), ICD. 
Blood samples were collected from the anterior v. cava every second week. The blood was allowed to clot and serum was obtained by centrifugation at $3,000 \mathrm{r} . \mathrm{p} . \mathrm{m}$. for $10-15 \mathrm{~min}$.

Enzyme determinations were carried out on the same and the following day. Lactate dehydrogenase activity was always examined on the sampling day.

The enzyme determinations were performed according to the procedure described in Sigma Technical Bulletin No. 505 (aspartate and alanine aminotransferase), No. 175 (isocitrate dehydrogenase), and No. 500 (lactate dehydrogenase). The activity of the respective enzymes is expressed as Sigma-Frankel (S-F) units, Sigma units, and Berger-Broida (B-B) units.

For tissue homogenate analyses, the procedure described by Wretlind et al. (1959) was followed with small modifications. The organs were removed as soon as possible from animals that died or were slaughtered. Tissue slices were rinsed in cold saline and kept frozen at $-20^{\circ} \mathrm{C}$ until analyses were performed at the end of the experiment. Homogenization was made with an Ultra Turrax homogeniser at a rate of 20,000 r.p. m. for $2 \mathrm{~min}$. The supernatant of a $10 \%$ homogenate suspended in isotonic phosphate buffer was used for aspartate and alanine aminotransferase determinations after centrifugation at 3,000 r.p. m. for 15 min.

The serum enzyme values given in the tables are mean values for the different lots. In order to give an idea of the development of the disease, initial values, average values for the whole experimental period, and mean end values at death or slaughter for all animals in the lot are given.

\section{RESULTS}

Serum enzyme activity

Experiment 1

Eight lots of four animals each were fed a basal ration with supplements as indicated in Table 1 . Lots $1-6$ received a $10 \%$ casein diet, lots $7-8$ got $16 \%$ casein. Lots $2,4,6$, and 8 were supplemented with vitamin $E$, lots 3 and 4 with Se and lots 5 and 6 with amino acids. $10 \%$ cod liver oil was given to all animals. For detailed feeding plan, see Table 1 (Nafstad \& Tollersrud 1970). The results of serum enzyme determinations are given in Table 1. 
Table 1. Mean serum activity of aspartate aminotransferase, alanine aminotransferase, and isocitrate dehydrogenase.

\begin{tabular}{|c|c|c|c|c|c|c|c|c|c|c|}
\hline \multirow[b]{2}{*}{ Lot } & \multirow[b]{2}{*}{ Diet } & \multirow[b]{2}{*}{$\left.1^{\star}\right)$} & \multicolumn{2}{|c|}{ AspAT } & \multicolumn{3}{|c|}{ AlAT } & \multicolumn{3}{|c|}{ ICD } \\
\hline & & & 2 & 3 & 1 & 2 & 3 & 1 & 2 & 3 \\
\hline 1 & $10 \%$ casein & 51 & 260 & 318 & 30 & 75 & 101 & 220 & 427 & 439 \\
\hline 2 & $10+E$ & 50 & 32 & 31 & 31 & 31 & 31 & 205 & 202 & 170 \\
\hline 3 & $10+\mathrm{Se}$ & 53 & 131 & 246 & 36 & 73 & 156 & 248 & 380 & 396 \\
\hline 4 & $10+\mathrm{Se}+\mathrm{E}$ & 52 & 36 & 32 & 40 & 29 & 34 & 241 & 215 & 164 \\
\hline 5 & $10+$ am.acids & 51 & 150 & 440 & 36 & 56 & 109 & 255 & 345 & 655 \\
\hline 6 & $10+$ am.a. $+E$ & 45 & 33 & 35 & 36 & 28 & 34 & 170 & 193 & 144 \\
\hline 7 & $16 \%$ casein & 41 & 329 & 708 & 30 & 44 & 60 & 220 & 664 & 1386 \\
\hline 8 & $16+\mathrm{E}$ & 50 & 63 & 114 & 31 & 24 & 35 & 216 & 381 & 679 \\
\hline
\end{tabular}

*) 1 - mean initial value.

2 - mean value for the experimental period.

3 - mean end value.

From Table 1 it may be seen that all lots which were supplemented with vitamin $\mathbf{E}$ maintained low levels of all three enzymes investigated. An exception is lot 8 where one pig (no. 4) at the end of the experiment showed a marked elevation of all enzymes and thus increased the mean values of this lot. Pathological examination of the pig, however, revealed no detectable organ lesions.

Among the vitamin E-deficient pigs, which all reflected increased enzyme levels, the most pronounced elevations were found in lot 7 , fed the highest protein level. Very high values were found of aspartate aminotransferase and isocitrate dehydrogenase, whereas alanine aminotransferase activity was moderately increased. This constellation should indicate a liver affection, and from Table 3 (Nafstad \& Tollersrud) it can be seen that hepatosis diaetetica was the dominant pathological diagnosis of all pigs in this lot. In lots 1,3 , and 5 higher values of alanine aminotransferase were observed together with increased aspartate aminotransferase and isocitrate dehydrogenase activity. Myocardial and/or muscular changes were thus expected and found, besides liver injuries.

The vitamin E-deficient lots supplemented with selenium or amino acids showed markedly higher enzyme values than when $\alpha$-tocopherol was added to the same diet.

A high incidence of gastric ulcers in the vitamin E-supplemented lots, described in detail by Nafstad et al. (1967), gave in no case elevated serum enzyme values. 


\section{Experiment 2}

Twelve pigs were fed a basal diet containing $10 \%$ casein and addition of amino acids. Instead of the $10 \%$ cod liver oil used in Experiment 1, $5 \%$ was given in this experiment. Half of the animals were supplemented with vitamin E. Two pigs in each group were fed a commercial swine concentrate mixture for the first 40 days in experiment. Results of serum enzyme determinations are given in Table 2.

Table 2. Mean serum activity of aspartate aminotransferase, alanine aminotransferase, and isocitrate dehydrogenase.

\begin{tabular}{|c|c|c|c|c|c|c|c|c|c|c|}
\hline \multirow[b]{2}{*}{ Lot } & \multirow[b]{2}{*}{ Diet } & \multirow[b]{2}{*}{1} & \multicolumn{2}{|c|}{ AspAT } & \multicolumn{3}{|c|}{ AlAT } & \multicolumn{3}{|c|}{ ICD } \\
\hline & & & 2 & 3 & 1 & 2 & 3 & 1 & 2 & 3 \\
\hline 1 & basal + am.acids & 39 & 254 & 515 & 23 & 77 & 138 & 261 & 470 & 838 \\
\hline 2 & basal+am.a. +E & 37 & 42 & 30 & 23 & 32 & 25 & 248 & 216 & 201 \\
\hline
\end{tabular}

The vitamin E-supplemented pigs showed during the whole experiment serum enzyme values within normal limits. No pathological changes were observed at necropsy (Table 4, Nafstad $\&$ Tollersrud). The non-supplemented lot developed highly increased values of all three enzymes, indicating that hepatic as well as myocardial and/or muscular changes had taken place. From Table 4 (Nafstad \& Tollersrud) it is further seen that the dominant pathological diagnoses included both hepatosis diaetetica and "Mulberry heart".

It is noticeable, however, that pig no. 3 in this lot, with the dominant pathological diagnosis of "Mulberry heart", had by far the highest serum levels not only of both transferases, but also of isocitrate dehydrogenase. The following values were observed on the day before death occurred: AspAT 1190, AlAT 330, ICD 3660 .

Highly increased levels of isocitrate dehydrogenase may thus be found in pigs mainly suffering from "Mulberry heart" disease.

Pigs no. 8 and 10, which were fed on commercial food for the first 40 days, and later on kept on a vitamin E-deficient diet, showed the following values at slaughter:

$\begin{array}{lccc} & \text { AspAT } & \text { AlAT } & \text { ICD } \\ \text { no. } 8 & 430 & 125 & 200 \\ \text { no. } 10 & 900 & 200 & 250\end{array}$


The constellation high aspartate and alanine amino transferase and normal isocitrate dehydrogenase should theoretically imply myocardial and/or muscular injury with no liver damage. From the necropsy results it is seen that this was the case.

\section{Experiment 3}

Thirty-six pigs divided into 8 lots were fed diets as indicated in Table 3 and given in details in Table 1 (Nafstad \& Tollersrud). Only serum transferases were determined in this experiment. The results are given in Table 3 .

Table 3. Mean serum activity of aspartate aminotransferase and alanine aminotransferase.

\begin{tabular}{lcrrrrrr}
\hline & & \multicolumn{3}{c}{ AspAT } & \multicolumn{3}{c}{ AlAT } \\
Lot & Diet & 1 & 2 & 3 & 1 & 2 & 3 \\
\hline 1 & basal & 51 & 279 & 365 & 24 & 103 & 63 \\
2 & $\# \quad+$ vit. E. & 39 & 30 & 32 & 21 & 22 & 25 \\
3 & $\#$ - pyridoxine & 37 & 189 & 184 & 17 & 64 & 53 \\
4 & $\#$ - pyridoxine + vit. E & 28 & 26 & 25 & 19 & 18 & 17 \\
5 & $\#$ + Se & 36 & 250 & 643 & 20 & 82 & 142 \\
6 & $\#$ + Se + vit. E & 33 & 38 & 45 & 19 & 24 & 28 \\
7 & $\#$ + amino acids & 35 & 253 & 865 & 22 & 56 & 88 \\
8 & $\# \quad+$ amino acids + vit. E & 33 & 45 & 39 & 22 & 25 & 25 \\
\hline
\end{tabular}

Serum enzyme values at a normal level were found only in the vitamin E-supplemented lots. Deficient pigs receiving selenium or amino acids (lots 5 and 7 ) developed the highest mean serum transferase activity.

Pyridoxine or pyridoxal-phosphate is a necessary coenzyme for aminotransferase reactions. Omission of this factor in the diet caused a tendency to decreased transferase values in lot 4 compared to other vitamin E-supplemented lots.

In animals which during the experiments showed temporary high increments of aspartate and alanine aminotransferases scar formations in the myocardium were almost regularly observed at necropsy. A high value in column 2 in relation to column 3 in the tables may thus suggest a period during the experiment with active tissue breakdown which later was healed by scar formations.

The highest alanine aminotransferase activity, the main source of which is heart muscle, was found in lots 5 and 7 . 
Diagnoses of "Mulberry heart" in these lots were thus expected to be predominant and were confirmed at necropsy (Table 5, Nafstad \& Tollersrud).

In this experiment, vitamin E-supplemented pigs which had developed gastric ulcers also showed normal enzyme values.

\section{Experiment 4}

Thirty-two pigs divided into 8 lots were fed diets as indicated in Table 4, and completely described in Table 2 (Nafstad \& Tollersrud).

In addition to serum transferases and isocitrate dehydrogenase, lactate dehydrogenase was determined. The results are given in Table 4.

T a b l e 4. Mean serum activity of aspartate aminotransferase, alanine aminotransferase, isocitrate dehydrogenase, and lactate dehydrogenase.

\begin{tabular}{|c|c|c|c|c|c|c|c|c|c|c|c|c|c|}
\hline \multirow[b]{2}{*}{ Lot } & \multirow[b]{2}{*}{ Diet } & \multicolumn{3}{|c|}{ AspAT } & \multicolumn{3}{|c|}{ AlAT } & \multicolumn{3}{|c|}{ ICD } & \multicolumn{3}{|c|}{ LHD } \\
\hline & & 1 & 2 & 3 & 1 & 2 & 3 & 1 & 2 & 3 & 1 & 2 & 3 \\
\hline 1 & $16 \%$ casein & 36 & 199 & 269 & 22 & 48 & 73 & 224 & 417 & 1,033 & 894 & 2,716 & 4,663 \\
\hline 2 & $16 \%+E$ & 37 & 33 & 28 & 21 & 28 & 25 & 234 & 174 & 123 & 966 & 767 & 753 \\
\hline 3 & cas. + soya & 32 & 79 & 220 & 22 & 31 & 28 & 175 & 286 & 428 & 823 & 2,081 & 2,488 \\
\hline 4 & cas. $+\operatorname{soya}+E$ & 29 & 39 & 43 & 21 & 25 & 29 & 198 & 203 & 201 & 896 & 884 & 955 \\
\hline $\mathbf{5}$ & $22 \%$ casein & 46 & 609 & 1,003 & 21 & 161 & 45 & 293 & 590 & 691 & 955 & 3,928 & 5,025 \\
\hline 6 & $22 \%$ cas. $+\mathrm{E}$ & 31 & 38 & 40 & 21 & 21 & 27 & 171 & 183 & 158 & 864 & 795 & 853 \\
\hline 7 & $36 \% \mathrm{~s}$ & 40 & 57 & 79 & 25 & 32 & 29 & 244 & 249 & 250 & 991 & 2,007 & 2,325 \\
\hline 8 & $36 \%$ soya $+E$ & 37 & 39 & 36 & 21 & 26 & 26 & 200 & 173 & 159 & 1,025 & 760 & 721 \\
\hline
\end{tabular}

From the enzyme values in Table 4 it would be expected that pigs in lots 1,3 , and 5 were suffering from some degenerative organ injury. Lots 1 and 5 , with casein as the only protein source, showed the highest isocitrate dehydrogenase levels, indicating a high frequency of hepatic disorders. This was confirmed at necropsy (Table 6, Nafstad \& Tollersrud). The elevated alanine aminotransferase activity in lots 1 and 5 suggested concomitant myocardial or muscular changes, which were also found in all animals in these lots. One pig especially in lot 5 (no. 477) seemed to have had a sudden and rather severe myocardial attack after eight weeks of experiment. Enzyme values were: AspAT 8880, AlAT 3850, ICD 1765, and LDH 10000. The values decreased rapidly, however, during the next fortnight and rose 
again towards the end of the experiment. Clinical symptoms were not noticed. The increased mean values of lot 3 are mainly due to pig no. 478, which had also shown a peak in the enzyme activity about 6 weeks before death. Myocardial scar formations were found at necropsy in both pigs.

The pigs in lot 7 , fed a $36 \%$ soybean meal diet without vitamin E-supplementation, revealed normal isocitrate dehydrogenase activity, moderately increased aspartate aminotransferase and elevated lactate dehydrogenase values. No liver damage should thus be expected. At necropsy myocardial scars were observed in all animals. These changes were probably the cause of the enzyme elevation. A more marked alanine aminotransferase activity, however, would have been expected under these conditions.

\section{Tissue enzyme activity}

In two experiments, 1 and 4, aspartate and alanine aminotransferase activities in homogenates of organ tissues from all animals were determined. In Experiment 1 only hepatic activity of the transferases was determined, in Experiment 4 liver, heart, and skeletal muscle (M. biceps femori) were analysed. In Fig. 1 mean levels of liver transferases of animals in Experiment 1 are

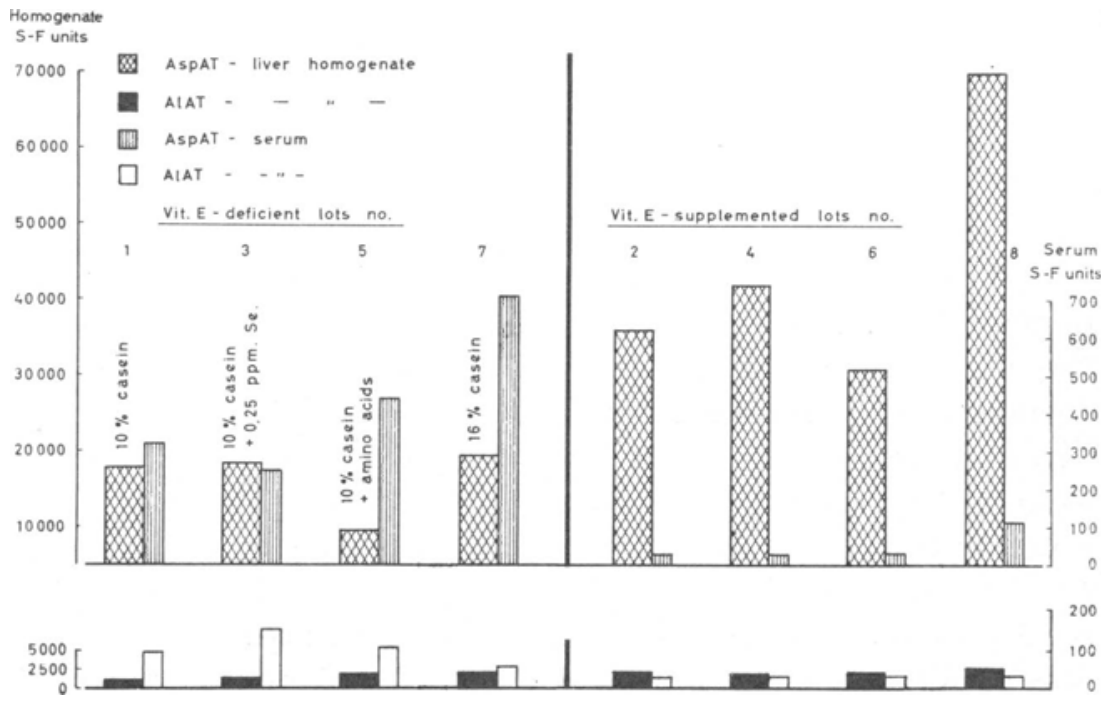

Figure 1. Mean liver and serum aspartate and alanine aminotransferase activities of the different lots at the end of Experiment 1. 
shown and compared to the last enzyme values recorded in serum before death or slaughter.

In vitamin E-deficient pigs high in serum aspartate aminotransferase a low hepatic activity of this enzyme was found. In the supplemented lots an inverse relation could be observed.

Liver alanine aminotransferase showed less marked differences between supplemented and non-supplemented lots.

The results of liver, heart, and skeletal muscle transferase determinations of animals in Experiment 4 are given in Table 5.

Table 5. Mean aspartate aminotransferase and alanine aminotransferase activity of liver, heart, and skeletal muscle homogenates.

\begin{tabular}{|c|c|c|c|c|c|c|c|}
\hline \multirow[b]{2}{*}{ Lot } & \multirow[b]{2}{*}{ Diet } & \multicolumn{2}{|c|}{ Liver } & \multicolumn{2}{|c|}{ Heart } & \multirow{2}{*}{\multicolumn{2}{|c|}{$\begin{array}{r}\text { Skeletal muscle } \\
\text { AspAT AlAT }\end{array}$}} \\
\hline & & AspAT & AlAT & AspAT & AlAT & & \\
\hline 1 & $16 \%$ casein & 15,525 & 690 & 55,100 & 7,133 & 4,933 & 1,400 \\
\hline 2 & $16 \%$ cas. $+\mathrm{E}$ & 36,225 & 1,375 & 82,275 & 9,825 & 19,950 & 2,088 \\
\hline 3 & cas. + soya & 52,838 & 1,961 & 83,300 & 11,267 & 14,550 & 1,875 \\
\hline 4 & cas. + soya $+E$ & 104,600 & 5,463 & 90,450 & 11,900 & 27,125 & 1,975 \\
\hline 5 & $22 \%$ casein & 48,563 & 940 & 75,900 & 7,800 & 18,425 & 1,738 \\
\hline 6 & $22 \%$ cas. $+\mathrm{E}$ & 96,825 & 4,700 & 86,925 & 11,000 & 28,475 & 2,300 \\
\hline 7 & $36 \%$ soya & 52,875 & 2,244 & 80,925 & 12,300 & 30,363 & 2,438 \\
\hline 8 & $36 \%$ soya $+E$ & 97,425 & 5,381 & 80,025 & 11,070 & 44,425 & 3,588 \\
\hline
\end{tabular}

The enzyme activity of tissue homogenates showed a great variation between organs as well as between different lots. A marked and constant difference, however, could be recorded between vitamin E-supplemented and non-supplemented lots. Considerably higher values were thus found, especially in liver and skeletal muscle homogenates, in pigs from lots $2,4,6$, and 8 than in the corresponding vitamin E-deficient lots.

As in Experiment 1, an inverse relation existed between the enzyme activity in tissue homogenate and blood serum at death or slaugther. This observation and the strongly varying tissue enzyme activity at different dietary protein levels will be discussed.

\section{DISCUSSION}

Serum enzyme changes have been extensively investigated in many diseases of man, and have been found to be useful aids to diagnosis and prognosis. In particular, elevated serum alanine aminotransferase levels in man usually indicate liver cell damage. 
Cornelius et al. (1959) and Wretlind et al. (1959) have stated that this is not the case in pigs. It is important to realize that properties of an enzyme may vary with species, tissue of origin, cell type and even with the subcellular location of an enzyme (Boyd 1962). It follows that a single assay system will probably not provide the optimum conditions for measuring the full activity of an enzyme, from all of a series of different organs. The results of this work represent enzyme activities under a given set of conditions, and may give only an approximation of the absolute amounts of an enzyme present.

The serum transferase levels of vitamin E-supplemented animals compare well enough with the values obtained by others from normal pigs. Wretlind et al. found in 36 pigs two to seven months of age the following mean values $\pm \mathrm{s}$ : AspAT 28.0 \pm 15.4 , AlAT 20.4 \pm 5.5 S-F units. Cornelius et al. report: AspAT $31.1 \pm$ 14.1, AlAT 27.3 \pm 7.8. Tollersrud (1969) found in 16 normal pigs four months old: AspAT 40.1 \pm 16.7 , AlAT 25.4 \pm 4.0 .

Other investigators as Grant (1961) and Tollerz (1965) have found serum aspartate aminotransferase determinations of value in studies of muscular dystrophy and related disorders in pigs. Grant, however, found it hazardous to use this aid to determine the effectiveness of treatment.

Cornelius (1961) found elevated serum isocitrate dehydrogenase activity in experimental hepatic necrosis in horse, calf, and sheep. Values for pig serum have not been available from the literature. The author tested 32 normal three months old pigs and found a level of $222 \pm 100$ Sigma units per ml.

Total serum lactate dehydrogenase of 16 normal pigs at an age of four months was found by Tollersrud to be $991 \pm 188 \mathrm{~B}-\mathrm{B}$ units.

In experiments on diseases of a complex nature like the vitamin E-deficiency in pigs, ascertainments of normal serum enzyme levels may be of greatest interest. In pigs with serum values within the normal range no major pathological organ changes, with the exception of gastric ulcers, have been observed in these experiments.

Increases of serum enzyme activity, on the other hand, have to a very great extent been associated with organ lesions. Regular and frequent blood sampling from experimental animals may thus give valuable information about the development of the deficiency syndrome. Enzyme tests are very sensitive, and an 
elevation in serum activity is usually found before pathological changes or clinical symptoms are observed.

To differentiate between the origin of enzyme release in a disease where so many organs may be involved must be considered more uncertain. None of the enzymes used in these investigations is organ specific. The fact that injuries of one organ can affect another contributes also to making a clearcut differential diagnosis less reliable. As shown by Nafstad \& Tollersrud (1970) an acute centrilobular liver necrosis, probably due to vascular congestion in the later stage of the disease, is often found in pigs suffering mainly from "Mulberry heart". This may explain the highly increased serum isocitrate dehydrogenase values such as those of pig no. 3 in Experiment 2.

Nevertheless, in many cases a good agreement existed between the expected predominant organ injury based upon the serum enzyme constellation and what was found at the pathological examination.

Determinations of lactate dehydrogenase isoenzymes in serum could possibly give additional information about the source of tissue responsible for the enzyme leakage. Lactate dehydrogenase is heterogeneous and has been separated into five electrophoretically distinct fractions. Human heart muscle has been shown to yield mainly fast-moving fractions, whereas liver tissue contains the slow-moving isoenzymes.

Hyldgaard-Jensen \& Jensen (1967) found in pigs that heart muscle yielded mainly fast-moving isoenzymes, whereas the slowmoving fractions were characteristic of skeletal muscles. Swine liver was dominated by the intermediate types.

Boyd concluded that marked serum increases of glutamate dehydrogenase were probably diagnostic of liver cell damage, and Wretlind et al. reported a similar organ specificity of ornithine carbamoyltransferase.

The level of activity of an enzyme in serum is thought to be the result of the equilibrium between the rate of release from the cell and the rate of removal from, or inactivation in, the blood stream. Alanine aminotransferase is shown to disappear slowly compared to aspartate aminotransferase (Amelung 1960). The mitochondrial bound isoenzyme of the latter disappears even more rapidly from the blood than the soluble component regularly found in serum (Fleisher et al. 1961). It should not be surprising that a continuous leakage of enzymes from damaged cells 
would yield tissue homogenates with a lower activity, particularly of aspartate aminotransferase, than intact organs. It has earlier been found that enzyme activities in damaged liver tissue diminish simultaneously with an increase of the enzyme activity in serum.

The tissue concentration of transferases showed a great variation in the different lots. Even in vitamin E-supplemented animals with no pathological changes great differences occurred from the following values recorded by Wretlind et al.:

$\begin{array}{lcc} & \text { AspAT } & \text { AlAT } \\ \text { heart muscle } & 56,300 & 6,500 \\ & (43,000-68,000) & (5,800-6,800) \\ \text { liver } & 41,000 & 1,800 \\ & (23,000-49,200) & (1,500-2,200) \\ \text { skeletal muscle } & 14,700 & 2,800 \\ & (8,000-27,000) & (1,300-4,300)\end{array}$

Nothing, however, is said about the protein dietary level in their experiments. It has been demonstrated on rat liver that correlations exist between the levels of enzyme activity and dietary protein (Schimke 1962).

Tumbleson \& Meade (1966) found in pigs that liver homogenate alanine aminotransferase increased linearly with increasing levels of dietary protein from dried skim milk or soybean meal. When soybean meal was the source of protein, an increase in dietary protein level from eight to $20 \%$ doubled the enzyme activity.

In Experiment 1 considerably higher liver aspartate aminotransferase activity was found in lot 8 which received a $16 \%$ casein diet, than in the other vitamin E-supplemented lots fed $10 \%$ casein. Hepatic alanine aminotransferase activity was also somewhat higher on the highest protein level (Fig. 1).

In Experiment 4 much higher hepatic transferase activities were measured in the vitamin E-supplemented lots 4, 6, and 8, which received about $20 \%$ total digestible protein, than in lot 2 which was given $14.5 \%$ protein (16\% casein). The same tendency was observed in skeletal muscle while heart homogenates showed a less marked difference (Table 5 ). 
Apart from the reservations made concerning the absolute amounts of enzyme activities in the tissue homogenates, the fact that several of the vitamin E-deficient pigs died at an earlier age than the control animals, and that the organs were thus kept in a frozen state for a longer time before analysis, should also be taken into account.

\section{REFERENCES}

Amelung, D.: Untersuchungen zur Grösse der Eliminationsgeschwindigkeit von Fermenten aus dem Kaninchen-Serum. (Studies on the rate of elimination of enzymes from the rabbit serum). Hoppe-Seylers Z. physiol. Chem. 1960, 318, 219-228.

Boyd, J. W.: The comparative activity of some enzymes in sheep, cattle and rats - normal serum and tissue levels and changes during experimental liver necrosis. Res. Vet. Sci. 1962, 3, 256-268.

Cornelius, C. E., J. Bishop, J. Switzer \& E. A. Rhode: Serum and tissue transaminase activities in domestic animals. Cornell Vet. 1959, $49,116-126$.

Cornelius, C. E.: Serum isocitric dehydrogenase (SIC-D) activities in domestic animals with experimental hepatic necrosis and in equine hepatopathy. Cornell Vet. 1961, 51, 559—568.

Fleisher, G. A., K. G. Wakim, M. Pankow, D. Osborne \& L. Clapp: Presence of two glutamic-oxalacetic transaminases in serum of dogs following acute injury of the liver. Proc. Soc. exp. Biol. (N.Y.) 1961, 106, 283-286.

Grant, C. A.: Morphological and aetiological studies of dietetic microangiopathy in pigs ("Mulberry Heart"). Acta vet. scand. 1961, 2, Suppl. 3.

Hyldgaard-Jensen, J. \& Sv. E. Jensen: Mælkesyredehydrogenase (LDH) hos svin. II. LDH-isoenzymer i blodplasma og væv. (Lactic dehydrogenase (LDH) in pigs. II. LDH-isoenzymes in blood plasma and tissues). Kgl. Vet.- og Landbohøjsk., Inst. Sterilitetsforskn. Aarsberetn. 1967, 109-120.

Nafstad, I. \& S. Tollersrud: The vitamin E-deficiency syndrome in pigs. I. Pathological changes. Acta vet. scand. 1970, 11, 452-480.

Nafstad, I., S. Tollersrud \& B. Baustad: Gastric ulcers in swine. 3. Effects of different proteins and fats on their development. Path. Vet. 1967, 4, 23-30.

Report of the Commission on Enzymes of the International Union of Biochemistry, I.U.B. Symposium Series, Pergamon Press, Oxford, 1961, vol. 20.

Schimke, R. T.: Adaptive characieristics of urea cycle enzymes in the rat. J. biol. Chem. 1962, 237, 459_468.

Sterkel, R. L., J. A. Spencer, S. K. Wolfson \& H. G. Williams-Ashman: Serum isocitric dehydrogenase activity with particular reference to liver disease. J. Lab. clin. Med. 1958, 52, 176-184. 
Tollersrud, S.: Stability of some serum enzymes in sheep, cattle, and swine during storage at different temperatures. Acta vet. scand. $1969,10,359-371$.

Tollerz, G.: Studies on the tolerance to iron in piglets and mice with special reference to vitamin $\mathrm{E}$, synthetic antioxidants, and sodium-selenite. Thesis, Stockholm 1965.

Tumbleson, M. E. \& R. J. Meade: Effect of source and level of dietary protein on liver enzyme systems in the young pig. J. Nutr. 1966, 89, 487-494.

Wretlind, B., K. Orstadius \& P. Lindberg: Transaminase and transferase activities in blood plasma and in tissues of normal pigs. Zbl. Vet.-Med. 1959, 6, 963-970.

\section{SUMMARY}

In four experiments performed to study the pathology of vitamin E-deficiency in pigs (Nafstad \& Tollersrud 1970) serum enzyme determinations were carried out in order to obtain some information about the development of the deficiency syndrome.

The enzymes determined were aspartate aminotransferase (AspAT $=\mathrm{GOT})$, alanine aminotransferase $(\mathrm{AlAT}=\mathrm{GPT})$, isocitrate dehydrogenase (ICD), and lactate dehydrogenase $(\mathrm{LDH})$. Blood samples were taken every second week during the experiments, which lasted for three to four months each and included a total number of 112 animals. At death or slaughter organs were removed in two experiments for determination of tissue homogenate transferase activity.

A good correlation was shown to exist between the levels of serum enzyme activity and the frequency of pathological changes found at necropsy. Vitamin E-supplemented pigs showed enzyme values within normal ranges, whereas animals supplemented with selenium or amino acids and non-supplemented lots showed increased levels. To a certain extent differential diagnoses between the organs most affected could also be made on the basis of the enzyme values, though the complex nature of the deficiency syndrome in some cases rendered this more hypothetical.

Gastric ulcers gave no elevation of serum enzyme activity.

An inverse correlation was found between transferase activity in serum and tissue homogenates. Vitamin E-deficient pigs with high serum values yielded lower tissue enzyme activity than animals in the corresponding supplemented lots.

Pigs fed the highest dietary protein levels showed the highest tissue transferase activity. This was most marked for liver homogenates. 


\section{SAMMENDRAG}

Vitamin E-mangelsyndromet hos gris.

II. Undersøkelser over enzymaktiviteten $i$ serum og vev.

I fire fors $\varnothing$ ksserier som er utført for å studere patologien ved Evitaminmangel hos gris (Nafstad \& Tollersrud 1970), ble dyrene samtidig fulgt med regelmessige serumenzymbestemmelser for å undersøke utviklingen av eventuelle organforandringer.

De enzymer som ble bestemt, var aspartataminotransferase $($ AspAT $=$ GOT $)$, alaninaminotransferase $($ AlAT $=$ GPT $)$, isocitratdehydrogenase (ICD) og laktatdehydrogenase (LDH). Blodprøver ble tatt annenhver uke $i$ fors $\emptyset$ ksperioden som varte tre-fire måneder. I alt var 112 griser med i fors $\varnothing$ kene. Ved d $\varnothing d$ eller slakting ble det fra alle dyr i to fors $\varnothing \mathrm{k}$ tatt ut organer til transferasebestemmelse i vevshomogenater.

Det viste seg å være god overensstemmelse mellom enzymnivået i serum og frekvensen av patologiske forandringer som ble funnet ved obduksjon. Grisene i de grupper som hadde fått tilskudd av $\alpha$-tokoferol, viste enzymverdier innen normale grenser, mens dyr som ikke hadde fått E-vitamin, og de som hadde fått tilskudd av selen eller aminosyrer, viste forh $\varnothing$ yede verdier. I en viss utstrekning var det ved hjelp av disse serumenzymbestemmelsene mulig å stille en riktig organdiagnose in vivo, skjønt de komplekse forhold ved mangelsyndromet $i$ enkelte tilfelle gjorde en differensialdiagnose mer hypotetisk.

Mavesår ga ingen forøkelse av serumenzymaktiviteten.

Et inverst forhold ble funnet $i$ transferaseaktiviteten $i$ serum og vevshomogenater. Griser uten E-vitamin-tilskudd og med høyt serumenzymnivå, hadde lavere enzymaktivitet $i$ vevene enn dyr i tilsvarende grupper som hadde fått E-vitamin.

Griser som var fóret på de proteinrikeste dietter, hadde høyeste transferaseaktivitet $i$ vevene. Dette var mest utpreget for leverhomogenat. 